\title{
6 Inscriptions from Ethiopia. Encoding Inscriptions in Beta Mașāḥəft
}

\begin{abstract}
This paper describes the available corpus of inscriptions from the Ethiopian and Eritrean regions giving an overview of this documentation. Some of the challenges involved with the inclusion of these documents in the Beta Mașāhəft project are presented: the connection to already digitally encoded texts, the encoding of the parallel fidal (i.e. Ethiopian script) and transcribed text, and the structuring of the data for the pseudo-trilingual inscription RIÉ nos 185 and 270 (that also has a second copy).
\end{abstract}

Keywords: Ethiopia, Eritrea, epigraphy, EpiDoc, multiple copies

\subsection{Ethiopian and Eritrean Ancient Epigraphy}

The Ethiopian and Eritrean region, despite the small numbers of inscriptions (amounting to some hundreds), offers examples for several case studies and a wide variety of languages and material epigraphic typologies. A rough estimation of the available inscriptions, arranged in chronological order and with obvious overlapping, including the few produced in Ethiopian languages or by Ethiopians in Antiquity, Late Antiquity and Middle Ages outside of Ethiopia (Yemen, Sudan, and Egypt), gives the rough figures detailed below. ${ }^{1}$ Some of the entry numbers in the classical collection Recueil des inscriptions de l'Éthiopie des périodes préaxoumite et axoumite (RIÉ; Bernand, Drewes, \& Schneider, 1991) are distinguished by an additional mark. In a few cases, one number refers to more inscriptions. This is typically the case of the two sets of the so-called "pseudo-trilingual” royal inscriptions, RIÉ nos 185 and 270, which correspond to two sets of three parallel texts each, respectively in Ethiopic in South Arabian script (RIÉ nos 185 I and 185bis I), in Ethiopic in Ethiopic non-vocalized script (RIÉ nos 185 II and 185bis II), and in Greek language and script (RIÉ nos 270 and 270bis). All in all, the two entries RIÉ nos 185 and 270 include six distinct inscriptions. Moreover, after the publication of RIÉ in 1991, additional inscriptions were discovered

1 Islamic inscriptions, which are well represented, are excluded from this short survey because they belong to a tradition of their own.

Alessandro Bausi, Pietro M. Liuzzo, Universität Hamburg 
and published; notable among them are some new Sabaean (or Sabaic) inscriptions from Təgrāy (Kropp, 2011), some metal royal inscriptions from the early Aksumite period, and the funerary Greek inscription from Gumālā (Fiaccadori, 2003).

The ancient and medieval inscriptions can be classified as follows:

1) 179 items (RIÉ nos 1-179) for the pre-Aksumite inscriptions. Most of these inscriptions are in the South Arabian (Sabaean) language from the first millennium BCE, in the pre-Aksumite period. These inscriptions attest to the presence of Semites (Semiticspeaking people) in the region from the first millennium BCE; moreover, among the Sabaean inscriptions, a sub-group can be distinguished with linguistic features of its own. In some cases, the same artefact bears both standard Sabaean and nonstandard Sabaean texts. ${ }^{2}$

2) 90 inscriptions (RIÉ nos 180-269) from the Aksumite period. They comprise:

2.1) A few early Ethiopic inscriptions (RIÉ nos 180-184).

2.2) Also placed in this period are two recently discovered, now published, metal inscriptions (Gebreselassie, 2017; Nebes, 2017). Apparently of great importance, they bear royal names and, along with a previous example that is considered the earliest document of Ethiopic language (RIÉ no. 180), they were also inscribed on metal (probably bronze);

2.3) This group includes the great royal inscriptions from Aksum (with only RIÉ no. 195 from Marib in Yemen). Of paramount importance for the history of the region (RIÉ nos 185-195), they document, in particular, the conversion from a peculiar paganism (at variance with the South Arabian pantheon of pre-Aksumite times) to Christianity of King 'Ezānā around the first half of the fourth century. They also document the enterprise and military expedition of King Kāleb, especially important for having led to the conquest of South Arabia (Himyar) and to its control by the Aksumites for some years, in the second quarter of the sixth century CE. They also document, with the presence of biblical quotations, the likely accomplishment of the translation of the Bible into Gə'əz by the early sixth century at the latest. Finally, they document the decay of Aksum with the last larger Aksumite inscriptions, poorly written and at present hardly readable, where linguistic phenomena typical of the later period start to appear. Most of the royal inscriptions were intended to be parts of votive thrones. However, only the evidence of the bases is, to some extent, preserved. The inscriptions, which were probably used as backs and/ or side panels of the thrones, were removed over the course of time. They are found at present in various places at Aksum. Some have been discovered as

2 These inscriptions can be found also in the DASI, Digital Archive for the Study of pre-islamic Arabian inscriptions database, where 49 inscriptions come from Ethiopia and 26 from Eritrea [http://dasi.cnr. it/index.php?id=86\&prjId=1\&corId=0\&colId=0\&navId=0]. The map demonstrates the geographical continuity. 
they were reused as construction materials in private houses. These inscribed thrones certainly had the function of shaping the landscape and were part of a general plan where the iconic and emblematic meaning of the inscriptions played a particular role. One more point of interest is provided by the likely survival of the introductory protocol, as given by some of these inscriptions, in early medieval documents eventually preserved in Ethiopian archives and of which we have only scanty evidence in additional notes written on blanks of manuscripts, loose leaves and unbound quires. This evidence establishes a suggestive connection between archival practices and inscriptions.

2.4) Quite remarkable for its much disputed chronology (dated in a range between the ninth and the fourteenth century CE), the inscription from Ham, in Eritrea (RIÉ no. 232) provides an interesting case-study. Once built in the façade of an old half-ruined church dedicated to St Mary, along with other reused materials (including a second Greek inscription containing the monograms A $\Omega$ ), it has been moved and relocated inside the newly built church at Ham (in 1992). The inscription commemorates the death of a young woman and the selection of biblical passages of the text betrays and presupposes the use of a developed liturgy;

2.5) Others, all in Ethiopic (RIÉ nos 196-269).

3) 17 inscriptions in Greek, from the Hellenistic (one only, RIÉ no. 276, Monumentum Adulitanum, I) and Aksumite period (RIÉ nos 269-286). Among the inscriptions in Greek, the Monumentum Adulitanum is particularly remarkable. It consists of two inscriptions, the first is mutilated and the latter is acephalous; the first was issued by Ptolemaeus III (246-222 BCE), who is explicitly mentioned, whereas the latter part is due to an unknown Ethiopian king and was placed upon a throne. Neither of these inscriptions are preserved; they were copied and transmitted by Cosmas Indicopleustes in the Topographia Christiana, who also provides information on their material and arrangement. The Monumentum Adulitanum is also remarkable for having been used early by Johann Gustav Droysen as exemplary for his definition of "Hellenismus", in linguistic terms (Canfora, 1995, pp.15-18). A few years ago, an additional Greek funerary inscription from Gumālā was discovered and published (Fiaccadori, 2003).

4) One inscription in a known script (South Arabian of the type used in other Aksumite inscriptions), but in an unknown language (RIÉ no. 287), presumably still from the Aksumite period, is known, but not properly deciphered.

5) 98 inscriptions on objects (RIÉ nos 287-384): 5 seals (RIÉ nos 287-291), 18 small, inscribed bronze objects (RIÉ nos 292-309), 85 inscriptions on pottery, particularly from the city of Mațarā in Eritrea (RIÉ nos 310-384).

6) 59 rock monograms (RIÉ nos 385-443), particularly from the region of Qohayto in Eritrea. 
Excluded from the RIÉ repertory are several inscriptions, dated to a later period, on an artefact that is quite peculiar to Ethiopian Christianity, although its models or premises might go back to Coptic Egypt-the manbara tābot (plur. manāborta tābot), namely "altar chest" (Fritsch, 2010). The oldest altar chests are datable to the twelfth/ thirteenth century, in the so-called "Zagwe period". The manbara tābot is like a "chair" (manbar) that supports the altar. It can be made from one wooden block, or in rock or metal. The most remarkable examples that bear inscriptions, however, are all in wood. Particularly interesting is the connection between manbara tābot inscriptions and parallel texts transmitted in parchment manuscripts.

\subsection{Beta Maṣāḥəft}

The project Beta mașāhəft: Manuscripts of Ethiopia and Eritrea (Schriftkultur des christlichen Äthiopiens und Eritreas: eine multimediale Forschungsumgebung) ${ }^{3}$ is a long-term project funded within the framework of the Academies' Program (coordinated by the Union of the German Academies of Sciences and Humanities) under survey of the Akademie der Wissenschaften in Hamburg. The Hiob Ludolf Centre for Ethiopian Studies at the Universität Hamburg hosts the project and aims at creating a virtual research environment that manages complex data related to the predominantly Christian manuscript traditions of the Ethiopian and Eritrean Highlands. ${ }^{4}$ The structure of the project is very simple with a TEI encoded XML file for each textual unit, one for each person, place repository and manuscript. Among the records of this last type, there are also inscriptions as they constitute part of the Ethiopian written documentation. The complexity of the corpus of inscriptions related to the scope of this project is evident and no final decision as to the criteria for inclusion and exclusion has been made. The data structure of the project hosts the transcriptions of manuscripts with their descriptions, and the edition of the texts in a separate text edition. This model would fail for inscriptions whose text is much better published directly with the metadata. There are also other projects, like the DASI project, which have already made valuable editions in TEI XML of texts in this corpus, which need to be taken into account in the encoding to guarantee continued interoperability among the existing resources. We will describe in the following section how we plan to encode inscriptions in this context, giving some examples.

3 [https://www.betamasaheft.uni-hamburg.de/].

4 A preliminary technical description can be found in Liuzzo, 2017. 


\subsection{Inscriptions in Beta Mașāḥəft}

Especially relevant for the project are the inscriptions in ancient Ethiopic language (Gə`əz), regardless of the script used to write this language. The Greek inscriptions are also included for their historical relevance. The Beta Mașāhəft schema already enforces all of the EpiDoc specifications (Elliott et al., 2007) and the editions of texts validating to the project schema are also validated to the latest EpiDoc schema. We will describe here a few of the challenges encountered in the process of including these documents in the framework of the project: 1) the connection to digitally encoded texts that have already faced the problems of encoding a Semitic script (thus the need of working on and encoding the transcription), 2) the encoding of parallel fidal and transcribed text and 3) the structuring of the data for the pseudo-trilingual inscription RIÉ nos 185, 185bis, 270 and 270bis in the framework of the current project.

\subsubsection{The Challenges of Encoding Inscriptions in Semitic Scripts}

Inscriptions in Sabaean from Eritrea and Ethiopia are already published online within the DASI project (Avanzini et al., 2014). The Beta Mașāḥəft project does not currently include those texts directly, but will include links to the DASI editions online by means of a simple <ref $>$ element in a host XML file with the references. This has been produced from the XML corpus export by the project from which only the local ID, the main reference, the <respStmt $>$ and titles were taken to make a mini record with a link to the actual resource in the DASI project website. In fact, although both projects work in TEI XML, the terms of use of the data and the structure of the records does not allow for a direct import of the data. ${ }^{5}$

The latter project has developed a highly sophisticated encoding method for the onomastic features, which is perfectly consistent with the mark-up practices of Beta Mașāhoft and validates to its schema, although the scope of the project does not currently allow for as deep an annotation as the one carried out in DASI. The inscriptions in Gə‘əz encoded in Beta Mașāḥəft follow this encoding structure, especially for the techniques identified for overlapping semantic mark-up, allowing for a cross analysis of the inscriptions in the two projects.

The mark-up needs to be carried out on the transcription for these texts, especially with regard to the morphological aspects; this is also the approach taken by the TraCES project ${ }^{6}$ (Bausi, 2015) which includes morphologically annotated texts

5 Further cooperation is envisaged to integrate the collections and the mark-up of the inscriptions in the two projects.

6 [https://www.traces.uni-hamburg.de/] founded by the European Commission ERC-AG-SH5 - ERC Advanced Grant - Cultures and cultural production, grant number 338756. 
of inscriptions elaborated by Maria Bulakh. Once these last annotations are imported into Beta Mașāḩft it will be possible to interrogate the onomastic features annotated in DASI, together with the morphological features.

Although it is, in principle, no problem to annotate the transliteration instead of the text in the original script, the current search functionalities of the Beta Mașăḩəft online application ${ }^{7}$ prefer the fidal script and cannot perform a bidirectional conversion between fidal and transliteration for search purposes. ${ }^{8}$ To guarantee the presence of both an annotated text in fidal and transliteration (both are needed for the aims of our project and for interoperability purposes described above), texts of inscriptions are reproduced in both scripts. ${ }^{9}$ The following is an example with the first three lines of the inscription RIÉ 187

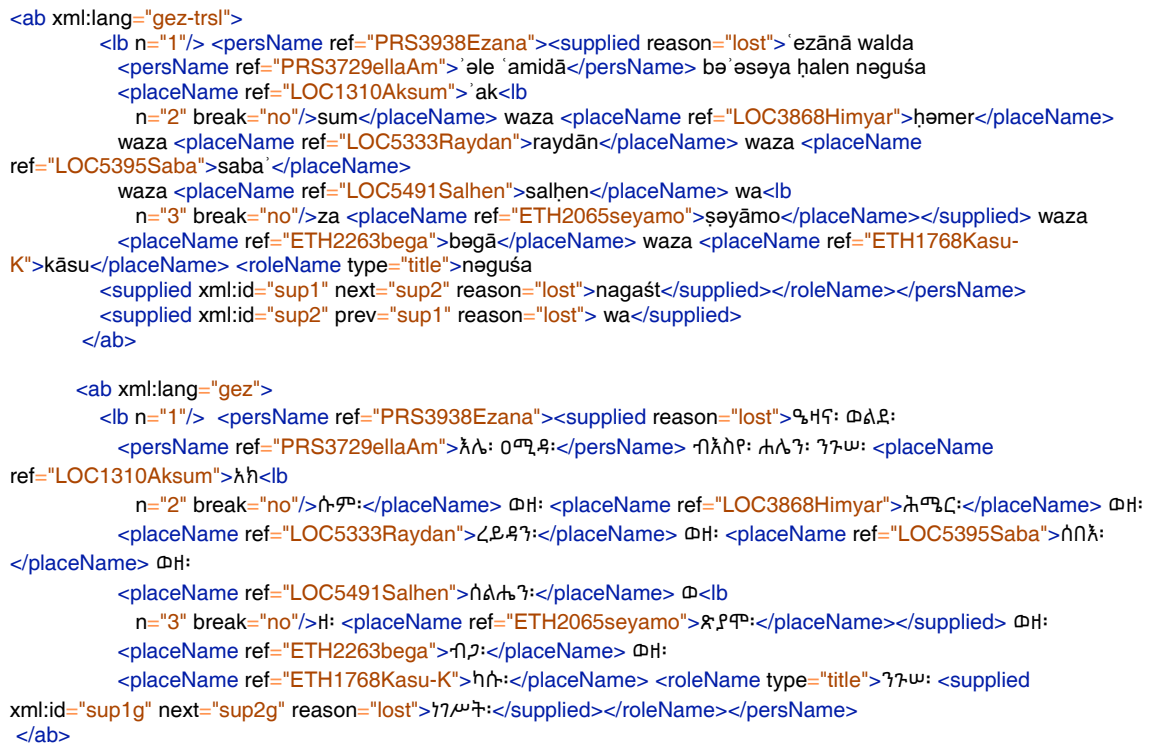

The parallel mark-up shows the identified named entities and provides data that can be queried to list forms of the title of the king, for example.

7 Not yet available online. Data is available, with full documentation, here: [https://github.com/BetaMasaheft].

8 This task is currently being elaborated under the TraCES project.

9 The transliteration is produced with code available also via this self-standing application: [https:// betamasaheft.github.io/transliteration/]. 


\subsubsection{Multilingual Inscriptions}

We will look now at the example of RIÉ 185, 185bis, 270 and 270bis. The texts of RIÉ 185 and RIÉ 270 and RIÉ 185bis and 270bis respectively, have been grouped in a single record for each stone to follow the praxis of one record for each manuscript. The concordance to the original references is preserved in the data. The internal text structure has been maintained inside the record, as also in RIÉ, instead of duplicating the record for the scripts employed. There are then two records in TEI XML for these two stones, which contain three parts each, and represent the actual distribution of the text on the different faces of the stone support.

The first problem posed by these texts is the relation between the three copies of the text in different scripts and languages and the relation between the main copy and the second copy. The first problem, as well as the changing text direction, is encoded in the diplomatic edition using @xml:lang. The second aspect is encoded in the XML data of Beta Mașāḩft using the relation element and properties from the SAWS ontology ${ }^{10}$ in its @name attribute.

<relation name="saws:isDirectCopyOf" active="RIE185bisand270bis" passive="RIE185and270"/>

The text has been edited in Ethiopic and Greek, and our record reflects this, leaving the transcription of the texts in their diplomatic form in the record about the stones, and the edition in a text. The relation among the stones and the text is made by means of the <listWit> element in the work records, and using @corresp attributes in the inscriptions records, corresponding to each relevant text part, as is generally the practice for the manuscripts and their contents' annotation in the project. The Gə'əz text will thus contain a list of witnesses.

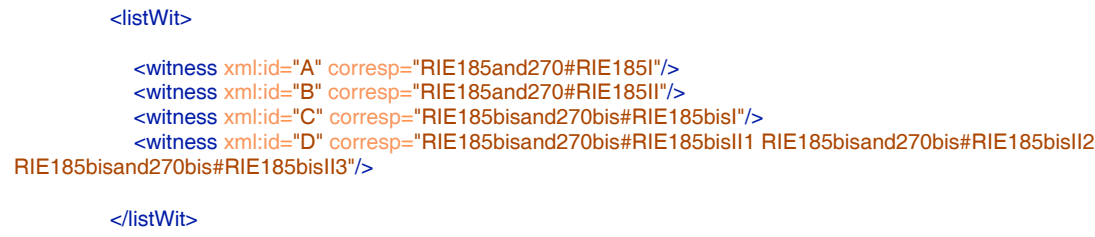

Here, it may be observed that we have to provide several IDs in the @corresp attribute of the witness $\mathrm{D}$, because in the description of this document, the actual text of this version is split over three faces of the stone. The structure of the text on the stone is reflected in the description of the inscription in XML as follows (text has been omitted).

10 [http://www.ancientwisdoms.ac.uk/]. 


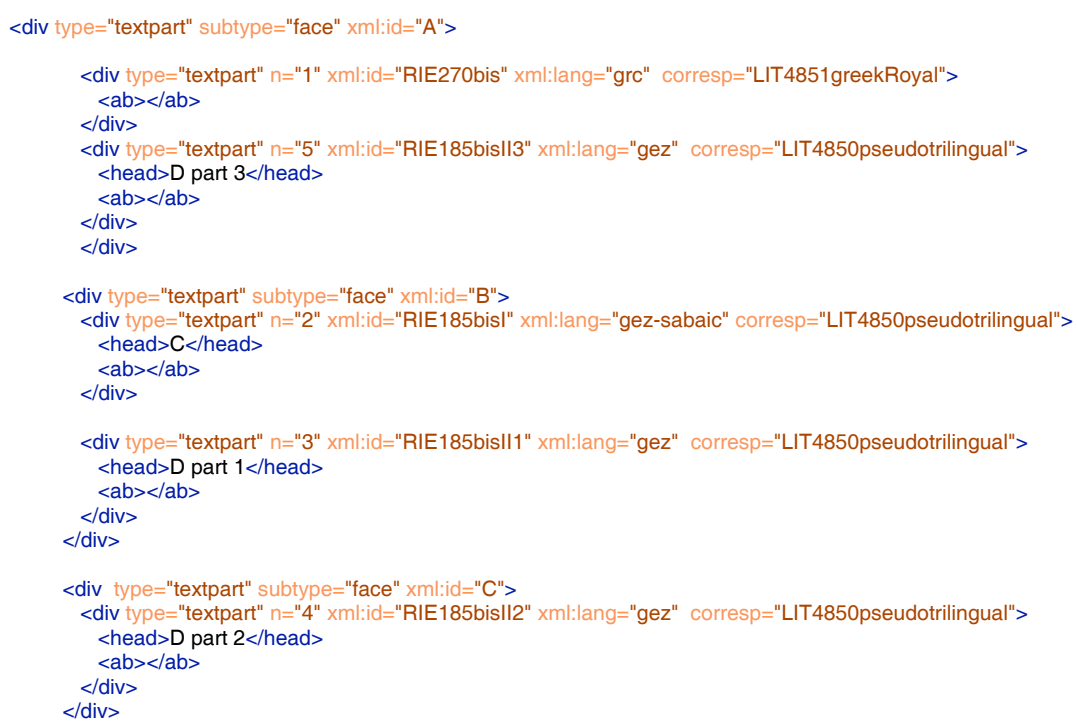

Note that the letters indicated traditionally for the four texts, are preserved both as abbreviation for the apparatus and as headers in the diplomatic edition. Also, the denomination of the different faces of the stone are preserved as @xml:id of the relevant text part.

The relation between the two texts, the Gə'əz and the Greek text, is stated in both records by means of another relation element.

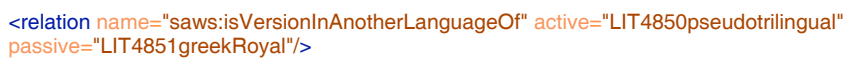

The editions of the texts do not need a line division, neither do they need to follow one of the scripts used, but the XML file can host any combination. The existing edition of the Gə'əz text elaborated by A. Bausi uses the transliteration as the RIÉ texts and it is encoded in this way.

\subsubsection{Inscriptions in Greek}

Further issues are presented by the encoding of Greek texts like RIÉ 276, mentioned above, known only through manuscript tradition. In this case, we may have only a work record in Beta Mașāḥft with the text of an edition of the inscription. This allows the text to be linked to other resources and reflects its status without forcing the presence of an inscribed support. However the manuscript does provide this information and we encode them in a specific manuscript record as in the previous example. The encoding of these texts does not present special issues and follows the schema of the project validating also to EpiDoc. 


\subsection{Conclusions}

Representing inscriptions along with manuscripts in The Beta Maṣāhəft project using TEI, while posing challenges, provides a clear and documented XML representation of the information, enabling connection with other XML resources like those in the DASI project. Ahead of us lies the challenge of integrating the encoding used for inscriptions in the DASI project with the morphological annotation exported from the TraCES project inside the Beta Mașāḥft project data structure and schema.

\section{Bibliography}

Avanzini, A., De Santis, A., Marotta, D., \& Rossi, I. (2014). Between Harmonization and Peculiarities of Scientific Domains. Digitizing the Epigraphic Heritage of pre-Islamic Arabia in the Project DASI. In S. Orlandi, R. Santucci, V. Casarosa, \& P.M. Liuzzo (Eds.), Information Technologies for Epigraphy and Cultural Heritage: Proceedings of the First EAGLE International Conference (Serie antichistica. Collana Convegni 26) (pp. 69-93). Roma: Sapienza Università Editrice. Retrieved from [https:// www.eagle-network.eu/wp-content/uploads/2015/01/Paris-Conference-Proceedings.pdf], 2017/11/30. doi: 10.13133/978-88-98533-42-8

Bausi, A. (2015). TraCES: From Translation to Creation: Changes in Ethiopic Style and Lexicon from Late Antiquity to the Middle Ages. In A. Bausi, A. Gori, D. Nosnitsin, \& E. Sokolinski (Eds.), Essays in Ethiopian Manuscript Studies. Proceedings of the International Conference Manuscripts and Texts, Languages and Contexts: the Transmission of Knowledge in the Horn of Africa, Hamburg, 17-19 July 2014 (pp. 11-13). Wiesbaden: Harrassowitz Verlag.

Bernand, É., Drewes, A. J., \& Schneider, R. (1991). Recueil des Inscriptions de l'Éthiopie des périodes pré-axoumite et axoumite. Introduction de Fr. Anfray; I: Les documents; II: Les Planches; Étienne Bernand, id., III: Traductions et commentaires, A: Les inscriptions grecques. Paris: Diffusion de Boccard.

Canfora, L. (1995). Ellenismo. Bari: Laterza.

Elliott, T., Bodard, G., Milonas, E., Stoyanova, S., Tupman, C., \& Vanderbilt, S. (2007, 2013). EpiDoc Guidelines: Ancient documents in TEI XML. Retrieved from [http://www.stoa.org/epidoc/gl/ latest/], 2017/12/09.

Fiaccadori, G. (2003). Un’epigrafe greca aksumita (RIÉth 274). In V. Ruggeri \& L. Pieralli (Eds.), Eukosmia. Studi miscellannei per il $75^{\circ}$ di Vincenzo Poggi S.J. (pp. 243-255). Soveria Mannelli: Rubbettino Editore.

Fritsch, E. (2010). Tabot: Mänbärä tabot. In A. Bausi \& S. Uhlig (Eds.), Encyclopaedia Aethiopica (Vol. 4: O-X, pp. 804b-807a). Wiesbaden: Harrassowitz Verlag.

Gebreselassie, Y. (2017). L'alphabet éthiopien. Une origine discutée. Dossiers d'Archéologie, $379=$ Éthiopie: un patrimoine exceptionnel, 34-37.

Kropp, M. (2011). Schriften und Sprachen im Kontakt: Sabäisch in Äthiopien und die ersten Zeugnisse der äthiopischen Sprache und Schrift. In S. Wenig (Ed.), In kaiserlichem Auftrag. Die Deutsche Aksum-Expedition 1906 unter Enno Littmann (Vol. II, pp. 323-337). Wiesbaden: Reichert Verlag.

Liuzzo, P.M. (2017). Encoding the Ethiopic Manuscript Tradition. In Proceedings of Balisage: The Markup Conference 2017 (Balisage Series on Markup Technologies 19). doi: 10.4242/ BalisageVol19.Liuzzo01

Nebes, N. (2017). The Inscriptions of the Aksumite King Ḥafil and their Reference to Ethio-Sabaean Sources. Zeitschrift für Orient-Archäologie, 10, 356-369. 